\title{
Appendix 1: Other manuscript versions of the chronicle
}

In Section 3 of the Introduction, the manuscript from which this diplomatic edition of the chronicle has been derived is described and, in Section 4, the reasons for choosing to present a diplomatic edition and the choice of the version found in NBG 101 are set out. This appendix surveys a selection of other versions of the work.

The most important point to come out of this survey is the confirmation of the status of the chronicle as a work in the sense defined in Section 2 of the Introduction. In this appendix, we describe a version as 'complete' if it conforms to the beginning and end of the NBG 101 version and contains most of the same content. Where a version is incomplete or contains additional material, especially at the end, there is usually a reason for this, and the version can be seen as a variant form of the work.

The survey is necessarily selective in several ways. The Bugis manuscript tradition contains a vast miscellany of historical information about Bone, much of it relating to the period covered by the chronicle. There are king lists, treaty texts, episodes, legal material and so on. The total quantity of manuscript material relating in one way or another to the history of Bone is probably at least equivalent to that for the history of Wajo as set out by Noorduyn (1955: 21-31) and even that exhaustive listing is by no means complete. The material described below is limited to that concerned with the chronicle, understood as a work.

The survey is also selective because life is short and the thorough cataloguing of Bugis manuscripts demands much patience and knowledge. We hope, however, that we have handled and consulted most of the older versions 
of the chronicle. We have had access to microfilm copies of the majority, as noted for particular manuscripts below. A major omission in our search for further versions has been the microfilm material held in the Arsip Nasional Republik Indonesia (National Archives of Indonesia) office in Makassar and listed in Mukhlis et al. (2003). Searching through this list, there are dozens of potentially relevant items, but most probably date from the twentieth century or have been covered in other ways. Undoubtedly, there are also versions in privately owned manuscripts across South Sulawesi that are not yet recorded.

As Macknight and Caldwell (2001) explain, the very nature of Bugis (and Makasar) literacy precludes the possibility of a neat stemma of manuscripts in a demonstrable phylogenetic relationship with each other, other than in exceptional cases. We have tried, in some detail, to compare variant versions of the chronicle, but the critical method, or recensio, does not work to produce a more 'reliable' version of the text. Alternatively, Macknight and Caldwell (2001: 151) suggest looking for groups of manuscripts and instance this work as an example of this procedure. Cummings (2007: 15-16) comes to very similar conclusions in respect of the manuscript versions of the Gowa chronicle.

Four other manuscript versions of the Bone chronicle form a group with NBG 101: NBG 100, Bone 5, Bone 20 and Andaya 2. These five manuscripts are distinguished by a combination of features, some of which are shared by other manuscripts, but not in combination. The common features are:

- Words are not divided, although this is common to many manuscripts. At least with NBG 101, NBG 100 and Bone 5, there are similarities in the handwriting.

- The codex does not contain significant other material in the Makasar language or relating directly to Gowa and cannot be shown to have been written in Makassar. The overall focus of the contents of each manuscript is on Bugis states, especially Bone.

- Although there is material missing in some when compared with the text of NBG 101, there is no additional material.

- They agree on one difficult point in the text: the phrase aja' mumarullé occurs towards the end of Chapter 1, where the first ruler gathers the people of Bone and tells them: 'Do not wriggle about.' All other versions have variant readings. 
A less clear group consists of NBG 208, Berlin 386 and Rylands Makassar 2. They all appear to be miscellanies of items in both Bugis and Makasar put together for non-local readers with various decorative touches. They date to various times during the nineteenth century and were probably copied in Makassar. There are significant textual differences between them, at least in terms of the chronicle, and Rylands Makassar 2, in particular, has some particular readings and content. This shows the range of material available to a scribe in Makassar in the nineteenth century. Further conclusions would require comparisons of all other items in a codex with other versions of each item.

Manuscripts are listed by the location of the original, where this is clear, or by the location of the microfilm or photocopy, if the whereabouts of the original is not known. Each item has been given a tag, such as NBG 99, for easy reference. The tag 'MAK' is used for the collection of the former Matthesstichting (Matthes Foundation) in Makassar, now the Yayasan Kebudayaan Sulawesi Selatan dan Tenggara (South and Southeast Sulawesi Cultural Foundation). The remaining original manuscripts of this collection are held in the office of the National Archives in Makassar. There are also microfilm copies of many items from the collection, including many items otherwise lost. Microfilm copies of manuscripts in the library of The Australian National University are noted; the Macknight reels are a series of microfilms held under the general title of 'South Celebes manuscripts—Naskah-naskah Sulawesi Selatan'.

\section{Leiden}

\section{Leiden University Libraries (Universitaire Bibliotheken Leiden) Southeast Asian Special Collections Loan collection of manuscripts from Dutch Bible Society (Nederlands Bijbelgenootschap)}

\section{NBG 99}

This is the base manuscript Matthes used for his edition of the chronicle-and other works -in the Boegineesche Chrestomathie (1864, 1872). It contains numerous linguistic notes, textual annotations and instructions to the printer, including marks for word division in the text, 
which, as written, does not divide words. The Bugis text is written on every third line, leaving space for interlinear comments, and the whole manuscript seems to have been produced for Matthes to work on. It is a large folio codex; the pages measure $39.5 \times 25 \mathrm{~cm}$, with an internal text covering $32 \times 18 \mathrm{~cm}$-apparently an account book of some kind. The text covers 290 pages with only 14 lines of text to the page. There are many blank pages after the text. It is on European paper, with no apparent watermark.

The chronicle starts at the top of page 171 and ends on page 217, line 4. The handwriting is clear and a little freer than that in NBG 101. The contents are listed by Matthes (1875: 32-5) and relevant items are included in Noorduyn's (1955: 21-31) list of material relating to Wajo. There is a microfilm copy in the ANU Library.

\section{NBG 100}

As Matthes (1875: 38) explains, he obtained this manuscript from Aru Padali, ruler of Tempe, and it is probably the manuscript he received in November 1861 (van den Brink 1943: 214). The text of the chronicle begins at the top of page 1 and ends at page 18 , line 25 . On page 14 , in the middle of line 24, the text jumps about three pages in a clear scribal error; in NBG 101, this is from page 14, line 10, to page 17, line 11, which is from Chapter 8 to Chapter 11.

The text covers 194 folio pages, with 29 lines to the page and no division of words. Pages measure $34 \times 21.5 \mathrm{~cm}$ and the internal text measures $30 \times 17 \mathrm{~cm}$. The watermark is Pro Patria in Dutch garden and L v Gerrevink. There are many blank pages after the text. A few pages from the end, there is further text with a date of AH 1273 (1856-57 CE). Matthes (1875: 38-9) describes the text as 'neatly and clearly written'the same terms he uses for NBG 101 - and the handwriting is indeed very similar and possibly by the same scribe. There are also many similarities in content to NBG 101, as listed by Matthes (1875: 35-8), and these are marked in the margin. Relevant items are included in Noorduyn's (1955: 21-31) list of material relating to Wajo. There is a microfilm copy in the ANU Library.

\section{NBG 101}

See Section 3 of the Introduction to this volume. 


\section{NBG 131}

A complete version of the chronicle text begins on page 35 , line 1 , and runs with 27 lines to the page to the bottom of page 57. A further sentence, which runs over into the first line of page 58 , deals succinctly with Arung Palakka's conquest of Tiworo and his return to Makassar. See Gaynor (2016: 97-106) for a detailed account of these events. There are also some further minor expansions of the text such as the names of all five children of the tomanurung on page 37 . There is extensive annotation, apparently by Matthes.

There are 115 pages of text, followed by about 20 blank pages. There are 27 lines to the page. Pages measure $33 \times 20.5 \mathrm{~cm}$, with an internal text of $26 \times 16.5 \mathrm{~cm}$, and watermark Pro Patria in Dutch garden over JH\&Z, and J. Honig \& Zoon. There is no word division. Contents are listed by Matthes (1875: 53). It contains other historical material about Bone, some items in Makasar and a copy of a Wajo chronicle listed as C2 by Noorduyn (1955: 23). There is a microfilm copy in the ANU Library.

\section{NBG 208}

A large folio codex containing a miscellany of historical items in both Makasar and Bugis. Matthes (1881: 6-16) distinguishes 183 items in its 254 pages. Pages measure $43.5 \times 21.5 \mathrm{~cm}$, with an internal text of $27 \times 15 \mathrm{~cm}$, and 31 lines to the page. There is no watermark. A final colophon records that Tajuddin completed the manuscript on 18 February 1877. Taken as a whole, the codex has the appearance of a compilation of historical material made in Makassar for a scholar interested in local history. It may even have been intended for Matthes, who completed his duties as director of the training school in Makassar in October 1879, about three weeks after Tajuddin died (Matthes 1881: 23; van den Brink 1943: 162).

The material relating to the Bone chronicle begins on page 95 and runs to page 132. This includes material on the rulers of Palakka and lists of ArumPone up to 1860 . The text is neatly laid out in paragraphs, with the first word of a new page quoted at the bottom of the preceding page. There is no division of words.

There is a microfilm copy in the ANU Library. 


\section{F.Or.A9}

A negative microfilm. A positive microfilm copy is also held in the ANU Library. A note in the first frame reads: 'Ex bibliotheca Regis Goa in insula Celebes.' The present whereabouts of the original is not known. A complete version of the chronicle is found at page 140, line 1, to page 173, line 15. In his unpublished notes held with the microfilm, Cense describes this section as

a piece of the history of Bone more or less agreeing with the text in the Boeginesche Chrestomathie, only here and there somewhat fuller, e.g. in this manuscript the children of the Manurung are names where they are lacking in the Chrestomathie.

The manuscript is written in several hands with a traditional palm-leaf quill in heavy black ink. The section starting from page 140 and ending at page 256, which deals first with this chronicle and then with some more detailed episodes in the history of Bone from the earliest times until the eighteenth century, and finally with a chronicle of Wajo, seems all to be by the same hand. For this section, there are 17 lines to the page. There is no word division. An earlier item claims to have been written in $1793 \mathrm{CE}$ (page 89), which provides a terminus post quem for the later sections.

Noorduyn (1955: 22-3) makes important use of this manuscript as his C1.

\section{F.Or.A42a [MAK 8]}

The chronicle begins on page 1 , line 14 , directly after a colophon with the date of 1830 CE. It is not clear how this date relates to the actual manuscript, which appears to be a standard Matthes Foundation copy made in the 1930s with 38 lines per page. The enclosed contents list says it has been copied from a manuscript belonging to 'A. Pan[?] in Tanete'. The chronicle text, which concludes on page 16 , line 24 , is a poor text, with some significant omissions as well as much minor variation. Words are divided, but with many errors.

A microfilm in Leiden appears to be the only record of Item 8 from the Matthes Foundation collection. There is also a microfilm copy in the ANU Library. 


\section{Berlin}

\section{Berlin State Library (Staatsbibliothek Preussischer Kulturbesitz) Ms. orient. fol. 386}

\section{Berlin 386}

A fine volume with a book plate containing the arms and name of A.W. Schlegel von Gottleben, whose death in 1845 presumably provides a latest date for the item. A date of 1729 appears on page 3 with a comment that this is 226 years after the disappearance of Makkalempié.

It has 162 pages, measuring $29.8 \times 19.4 \mathrm{~cm}$, with 21 lines of text written within c. $25 \times 15.5 \mathrm{~cm}$. The watermark is IWB and VI, with Dutch garden and Pro Patria.

The chronicle text begins on page 6 , line 1 , and runs to page 47 , line 15 , with nothing further on the page. There is no word division. Some sections are introduced by several lines in red and with expanded spacing, and some names are also in red. The contents are listed by Matthes (1875: 99-101). The codex contains a miscellany of Bugis and Makasar historical and religious works in both Lontara and Arabic scripts. The Bone chronicle is the longest item. There is a clear interest in Bone and Matthes argues that the copyist was Bugis. The Bone chronicle text is generally close to NBG 101. Cummings (2007: 14) describes the material relating to Gowa in this codex.

There is a microfilm copy in the ANU Library.

\section{Manchester}

\section{John Rylands University Library}

\section{Makassar 2}

The Bone chronicle begins at the top of page 37, with the heading 'attoriolongngé riBoné. The usual text runs to the To Bala defeat at page 85 , line 16 , and then continues to page 89 , line 6 , with an account of Arung Palakka's escape from demeaning service in Gowa and eventual 
flight from Palletté in Bone to Butung and eventually to 'Jakettara'. This alternative ending throws more light on the early career of Arung Palakka, but also has the effect of omitting any mention of the seven years of Arung Amali's role in Bone and of the events in and around Butung in 1666-67 involving not just Arung Palakka, but also the Dutch East India Company.

The codex of 110 pages, measuring $20.3 \times 15.8 \mathrm{~cm}$ on blue European paper, also contains a version of the Gowa chronicle and four Malay hikayat. The Bugis script is very clear with no word division, but much underlining marks many words. A series of large Roman numerals heads the sections of successive rulers; the series begins in the preceding version of the Gowa chronicle and continues from IX to XXIII for the Bone chronicle. On page 89, there is then a colophon saying that the copying of this item concluded in Kampong Melayu, Makassar, on Wednesday, 7 September 1859. A similar colophon on page 35 dates the completion of copying of the Gowa chronicle to 31 August 1859.

The mixed contents and clear script suggest the codex was prepared for a European collector in the nineteenth century. It was in Britain by 1901 . It is described and the contents are listed in Ricklefs and Voorhoeve (1977: 100).

\section{Jakarta}

\section{National Library of the Republic of Indonesia (Perpustakaan Nasional Republik Indonesia) VT Collection [Verschillende talen or Miscellaneous languages]}

\section{VT 84}

A fairly complete version of the chronicle text begins in the middle of page 281 (bottom nine lines) and runs with 25 lines to the page, to page 308 (19 lines). The writing is clear and confident, with a tendency to add fancy swirls. Words are defined by spaces. Pallawa are indicated by both three dots and a stroke. At the bottom of right-hand pages, a tag of several aksara is given for the top of the succeeding page. Many personal names are underlined, and most reigns are marked with Arabic and Roman numerals in the margin. 
In addition to the usual minor variations from NBG 101, there are more significant differences. On page 298, after the account of the treaty at Timurung, there is a diagram of three sets of four concentric circles named as the three states. Soppeng has a strange hernia-like protrusion. The names and an explanatory caption are additions to the NBG 101 text. There is also a significant omission. At page 302, line 9, the text jumps from NBG 101, page 15, line 22, to page 16, line 20. This gap of about a page probably represents the copyist jumping from one page to another in his model.

The manuscript is noted in Behrend (1998: 316) and a detailed contents list is given by Cense (n.d.: 3-4). Cense gives the dimensions as $33 \times 21 \mathrm{~cm}$. This is a substantial codex of 394 pages containing the usual miscellany of historical, legal and religious materials, including other historical information on Bone and much on Soppeng. The name 'Perné Pinrang' inside the cover suggests a European owner at some point. There is a microfilm copy in the ANU Library and a digital version on the Perpustakaan Nasional website.

\section{VT 124}

A complete version of the chronicle text begins on page 8 , line 1 , and runs with 25 lines to the page, to page 32 , line 17 . There is no word division.

The manuscript is noted in Behrend (1998: 318) and a detailed contents list is given by Cense (n.d.: 5-6). Cense gives the dimensions as $31.5 \times 20 \mathrm{~cm}$. This is a codex of 96 pages containing mainly historical material. From page 47, it is in Makasar. There is a microfilm copy in the ANU Library (Macknight, Reel 21, Item 5) and a digital version on the Perpustakaan Nasional website. See also Cummings (2007: 14) on this manuscript.

\section{Watampone, South Sulawesi}

\section{Various locations}

\section{Bone 1}

A complete chronicle text starts at the top of page 19A, with a preliminary title in a circle, and runs, with 36 lines to the page, to page 27A, line 23. It is clearly written with some names picked out in larger script and many emendations. Words are consistently divided. 
The manuscript consists of folders loosely bound between red cardboard covers. Pages are numbered by double-page spread and the same number is found in the left and right upper corners of each spread. There are 135 spreads - that is, 270 pages, measuring $32.5 \times 21 \mathrm{~cm}$. There is a contents list for the usual variety of items, many of historical interest.

On the initial flyleaf, the manuscript is described as 'Lontara Keradjaan Bone'. It is said to belong to A. Muh. Ali, and to have been copied in 1947 from a manuscript owned by Andi Paworeki Petta Renring. This statement is signed by A. Muh. Ali. There is also a stamp of the Bone Kantor Kebudayaan (Cultural Office). In 1972, when the manuscript was filmed, A. Muh. Ali was the head of that office. Many items are headed in modern Indonesian and there are various inserted notes and guides, such as a typed list of Dutch officials in Bone from 1905 to 1948. This manuscript is the product of a person with modern Indonesian literacy and a strong interest in local history, very probably A. Muh. Ali himself. The ANU Library holds the microfilm as Macknight (Reel 8, Item 1).

\section{Bone 5}

The chronicle text starts at the top of page 2, though a substantial portion of the top of the page has been torn away, affecting the first five lines. It then continues, with 31 lines to the page, to the bottom of page 15, where it ends with a statement in Bugis that this is the end of the work and an elaborate tammat and Arabic phrase. The handwriting is mostly small and clear, with some sections-apparently random-in a larger hand. This variation is seen in other items in the codex. There is no word division in the text.

The codex, in a fine embossed brown leather cover, runs to 162 pages, measuring $33 \times 20.5 \mathrm{~cm}$. The front flyleaves claim it is owned by Andi Pabbara and by Petta Lolo Mappaseling/Andi Mappaseling. In 1972, it was manuscript Number 5 in the Cultural Office in Watampone when it was filmed and the microfilm is now to be found in the ANU Library (Macknight, Reel 8, Item 2). In May 1982, photocopies of the codex were made by Muh. Salim, one of which, entitled 'Lontarak attoriolong riBone', is also held in the ANU Library. A card captured in the photocopy of what seems to be a cover notes that the manuscript was registered on 15 IV 1974, but the significance of this is unknown.

A contents list, in both typescript and handwriting, contains 146 items, mainly of historical interest, but with much else besides. 


\section{Bone 20}

This is a good example of a fragment of the chronicle text. This begins on page 91 , line 1 , and runs to page 99 , line 15 , with nothing further on the page. This covers from the beginning of the chronicle to near the end of Chapter 3, where it ends abruptly at the equivalent in NBG 101 of page 6 , line 4 up.

The manuscript contains 105 pages of clear text, as well as various notes. Pages 14 and 15 are missing. There is a table of contents in the front showing most items are concerned with Bone. Pages measure $27 \times 18.5 \mathrm{~cm}$, with 19 lines to the page. There is no word division. The paper appears to date from the nineteenth century, although no watermark is apparent. The front cover, the flyleaf and the torn original cover all contain the name Andi Rajeng Petta Lebbi', presumably as the owner. The name of A. Muh. Ali also appears on the front cover.

The manuscript was filmed in 1978 at the house of Muh. Rafi in Watampone and the microfilm is held by the ANU Library as Macknight (Reel 24, Item 1).

\section{Canberra}

\section{ANU Library}

\section{Andaya 2}

An almost complete chronicle text starts on page 31, line 14, and runs to page 48, line 31, where the text ends with the death of Matinroé riTallo'. Another item begins immediately, and it is not clear why the text ends at this point. The handwriting is slightly clumsy, but usually clear. Words are divided, if not always accurately. Occasional deletions and corrections suggest the scribe was following a model, though not necessarily precisely. There are many minor differences from the NBG 101 text.

This codex is the second of a series of six photocopied volumes obtained by Dr Leonard Andaya in 1976 and lodged in the ANU Library. Pages are numbered in heavy figures at the top of the page. The numbering begins at page 27 and runs to page 140; it seems these 113 pages reflect a fragment of an original codex. 
This text is taken from The Bugis Chronicle of Bone, translated and edited by Campbell Macknight, Mukhlis Paeni and Muhlis Hadrawi, published 2020 by ANU Press, The Australian National University, Canberra, Australia.

doi.org/10.22459/BCB.2020.02 